\title{
Mapping the Research Productivity on Water Conservation: A Scientometric Analysis
}

\author{
Dr.PrabakarStanleay ${ }^{1}$, Dr.M.Nagarajan ${ }^{2}$, Dr.S.Sivankalai ${ }^{3}$ \\ \{stanleay@gmail.com¹, mnagarajanlib@gmail.com², skysivan@gmail.com ${ }^{3}$ \}
}

Librarian, B.I.H.E.R. - Deemed to be University, Selaiyur, Chennai. Orchid ID: 0000-0002-7079-

4219 ${ }^{1}$, Assistant Librarian, AMET - Deemed to be University, Kanathur, Chennai. Orchid ID: 00000003-0180-2462 ${ }^{2}$, Librarian, PSN College of Engineering \& Technology, Tirunelveli. Orchid id:0000$0002-1174-7594^{3}$

\begin{abstract}
The importance of "Water Conservation" and scientometric study has been highlighted in the introductory part of the article. A few literatures related to the scientometric study have been reviewed. To know the reflection of the responsibility of the global scientists to conserve the water towards the protection of the society is the aim of this scientometric study. The data selected for the scientometric study is limited to eight years from 2011 to 2018 and also the data is confined to the database "Web of Science". Appropriate hypotheses have been framed and tested with statistical tools such as Regression and Kolmogorov Smirnov Test. The deviation among the year wise number of publications are tested through Regression Test and found that the data are suitable for the calculation of doubling time. The minimum time to be taken for the doubling of records will be 5 months and 8 days and the maximum time to be taken for the doubling of records will be 9 months. The "Journal Articles' and the language "English" played dominant role over the entire period of research publications. .Kolmogorov Smirnov Test proved that Lotka's Law of author productivity does not fit for the research publications author productivity on "Water Conservation". The Bradford's Law identified that 25 journals are most productive. The article is concluded with a suggestion to the concerned global ministries and sponsoring bodies to encourage the scientists to enhance the "Water Conservation"..
\end{abstract}

Keywords: Scientometric, Water Conservation, Regression Test, Doubling Time, Lotka's Law, Kolomogorov Smirnov Test, Bradford's Law.

\section{Introduction}

Water is one of the prime resource facets to live in the earth for each and every living being is a well-known concept. "Water Conservation" is an act of potential to protect the society from disaster. Not only the deficiency of the water, but also the excess of water through natural calamities such as flood and heavy rain will also bring disaster to the lives of this earth, if the water has not been conserved properly. Therefore, appropriate conservation of water is very much essential for the entire global countries. An article accessed from Google, clearly depicts that 96.5 percent is the volume of water on the surface of the earth and out of which, 2.5 percent are usable freshwater. The volume of freshwater in the form of icesheets and glaciers are 70 percent and the remaining 30 percent are stored in ground. ${ }^{1}$ How the act of "Today's News will be the History of tomorrow", likewise, "Today's Conservation of 
Water will be enacted as Lives for the society, tomorrow". Water can be conserved through appropriate maintenance of ponds, lakes, rivers, dams, drip irrigation system and rain water harvesting. Some of the pictures collected from Wikipedia on "Water Conservation" are displayed below in figure number 1 and 2 to have a clear visualization.

Scientometric is a powerful metric to device the research output of any discipline, any individual scientist, educational institutions, country wise publications, language wise publications, document wise and journal wise publications. The data for the scientometric study can be collected either from print media or from an online indexing database such as Web of Science, Scopus, Google Scholar, and MEDLINE. Data for this research work has been downloaded from the core collections of Web of Science.

\section{Review of Literature}

Liu, Z., Lu, Y., \&Peh, L. C. (2019). The Scientometric analysis was done on "Building Information Modelling". The data selected for the scientometric study was from 2004 to 2019. The data were collected from the Web of Science core collections. The analysis and visualization has been done by the Cite-Space software. The research study reveals that 1455 literatures were published from 2004 to 2019 and the same has been graphed in the article. The year 2018 was most prolific. The table number two shows the top ten authors. Xiangyu Wang of Curtin University located in Australia was placed first in the table with a record count of $41(2.82 \%)$. USA published most number of research papers with 341 publications. "Curtin University" of Australia published maximum number of research publications of 69 records. The journal "Automation in Construction" was most productivity with 294 research papers. The research publications have been bifurcated into three layers viz., (i) Formulating Stage, (ii) Accelerating Stage and (iii) Transformation Stage. ${ }^{2}$ Sivasamy, K., \&Vivekanandhan, S. (2015). The scientometric research assessment was done on "Environmental Education". The selected years for the research work were from 2009 to 2013. Required data for the scientometric research was downloaded from SCOPUS. It was identified that 2062 number of research papers were indexed in SCOPUS on "Environmental Education". The degree of collaboration was 0.68 , which means a fair collaboration between the authors involved in publishing research publications on "Environmental Education". It was identified that USA published maximum number of research publications of $515 .{ }^{3}$ Morooka, K (2014) the bibliometric study reveals the rise research and technology development of Japanese. The research period of the study was from 1990 to 2000. The research period has been bifurcated into two segments i.e., from 1990 to 1994 and from 1995 to 2000. It was identified that there was more frequency distribution among two periods between the subject disciplines, except biology. A total of 9389 articles were published in 1611 journals from the year of 1990 to 2000. The Bradford's law has been applied to categorize the publications into three zones to identify the core journals. The first zone was more productive publications through less number of journals. The second zone reveals that more number of journals were utilized to produce less number of articles. The third zone shows all the journals, which are responsible for publishing least number of articles. But, at the outset the three zone reveals the entire structure of the research output of the research and technology development of Japanese. ${ }^{4}$ Ren, J. L., Lyu, P. H., Wu, X. M., Ma, F. C., Wang, Z. Z., \& Yang, G. (2013). The research output on "Water Resources" indexed in Web of 
Science from 1993 to 2008 has been taken for the bibliometric study. The study period has been categorised into four span of years. The study reveals that 18 numbers of documents were involved towards producing 96574 numbers of publications. Out of which $62258(64 \%)$ were journal articles. The language "English" dominated the research with a publication count of 60793 with an h-Index of 151. Cumulative numbers of publications were highlighted with pictorial representation. Bradford's law has been applied to identify the core journals and the law results that 59 journals were core journals that involved towards publishing 65528 articles. The country wise publications assessment states that two North American Countries were place in the top place followed by ten European countries, six Asian countries, South Africa and Australia. The institution wise assessment proves that US Geological Survey, USA leads the table with 1343 number of articles and $64 \mathrm{~h}$-Index. The most cited paper were identified as the articles published in "Water Research" by Terns in 1998 with a citation score of 630 times up to the year 2008. The article was concluded with a word of possibility of further research directions on "Water Research". ${ }^{5}$ Biglu, M. H., Eskandari, F., \&Asgharzadeh, A. (2011). The scientometric study was done on the basis of the data downloaded from MEDLINE database on "Nanotechnology". The study period taken for the research was from 2001 to 2010. It was identified that 11991 research publications were published during the stipulated ten years. "English language played dominant role in publishing 11775 (98.2\%) numbers of publication. The assessment of the type of publications reveals that the journal articles dominated the research publications with 41 percent of articles. USA leads the table with maximum numbers of publication with 55 percent and research papers with 39 percent. Time Series Analysis has been made by the author to find out that the "English Language" publications will reach almost double the publications in the year $2030{ }^{6}$

\section{Research Design}

\subsection{Need for the Study}

To know the reflection of the responsibility of the global scientists to conserve the water, as water is one of the prime factors for each and every living being to survive in this earth, by means of the assessment of their research contributions to enhance the "Water Conservation".

\subsection{Limitation of the Study}

Data for only 8 years from 2011 to 2018 are utilized. The source database is limited to only core collections of "Web of Science". The bibliometriclawutilized for this scientometric study is limited to the application and testing of Lotka's Law and Bradford's Law.

\subsection{Hypotheses}

1. H0: There is no significant relationship between the averages of the research publications

on "Water Conservation" from 2011 to 2018.

1. H0: There is no significant relationship between the actual author productivity and the

prediction of Alfred Lotka's author productivity theory. 


\subsection{Methodology}

Data related to the research publications indexed in "Web of Science" on Water Conservation" from 2011 to 2018 has been downloaded. Appropriate hypotheses are formulated. A few scientometric techniques along with statistical tools such as Regression Test and Kolmogorov Smirnov Test have been utilized towards the completion of the research. The research is descriptive in nature.

\section{Results and Discussion}

\subsection{Year wise Research Publications on Water Conservation}

The year wise research publications for 8 years tabulated in table number 4.1 reveals that a total of 2507 number of publications are published from 2011 to 2018. The percentage analysis is very clear that the growth of research publications on "Water Conservation" indexed in "Web of Science" inclined from one year to another year at a steady pace without any decline. The Local Citation Score with and without Self Citation have also been displayed. Local Citation Score, which includes self-citation score is 2108 and excluding selfcitation score is 1473 . The total number of publications of 2507 received 28506 as Global Citation Score for the above stipulated years.

\begin{tabular}{|c|c|c|c|c|c|c|}
\hline \multirow[b]{2}{*}{$\begin{array}{l}\text { No. of } \\
\text { Years }\end{array}$} & \multirow{2}{*}{$\begin{array}{l}\text { Year of } \\
\text { Publications }\end{array}$} & \multirow{2}{*}{$\begin{array}{l}\text { No. of } \\
\text { Research } \\
\text { Publications }\end{array}$} & \multirow{2}{*}{$\begin{array}{l}\text { Percentage } \\
\text { Analysis }\end{array}$} & \multicolumn{2}{|c|}{ Local Citation Score } & \multirow{2}{*}{$\begin{array}{l}\text { Global } \\
\text { Citation } \\
\text { Score }\end{array}$} \\
\hline & & & & $\begin{array}{l}\text { Including } \\
\text { Self Citation }\end{array}$ & $\begin{array}{l}\text { Excluding } \\
\text { Self Citation }\end{array}$ & \\
\hline 1 & 2011 & 227 & $9 \%$ & 361 & 275 & 4949 \\
\hline 2 & 2012 & 234 & $9 \%$ & 318 & 215 & 4266 \\
\hline 3 & 2013 & 263 & $10 \%$ & 416 & 297 & 5186 \\
\hline 4 & 2014 & 274 & $11 \%$ & 313 & 229 & 3958 \\
\hline 5 & 2015 & 316 & $13 \%$ & 298 & 210 & 3755 \\
\hline 6 & 2016 & 353 & $14 \%$ & 241 & 160 & 3062 \\
\hline 7 & 2017 & 391 & $16 \%$ & 140 & 77 & 2360 \\
\hline 8 & 2018 & 449 & $18 \%$ & 21 & 10 & 970 \\
\hline \multicolumn{2}{|l|}{ Total } & 2507 & $100 \%$ & 2108 & 1473 & 28506 \\
\hline
\end{tabular}

Table 4.1. Year wise Research Publications on Water Conservation

\subsection{Regression Test}

The table number 4.2 shows a clear picture about Regression Test. The test has been conducted to find out the results to accept or reject the null hypothesis framed as below:

H0: There is no significant relationship between the averages of the research publications on "Water Conservation" from 2011 to 2018.

The result of the regression test reveals that the P-value of 0.04 is lesser than the critical value of 0.05 , therefore the null hypothesis is rejected and an alternate hypothesis is being developed as:

H1: There is a significant relationship between the averages of the research publications 
on “Water Conservation” from 2011 to 2018.

\begin{tabular}{|c|c|c|c|c|c|c|c|}
\hline \multicolumn{3}{|c|}{ Regression Statistics } & & & & & \\
\hline \multicolumn{2}{|l|}{ Multiple R } & 0.96 & & & & & \\
\hline \multicolumn{2}{|l|}{ R Square } & 0.92 & & & & & \\
\hline \multicolumn{2}{|c|}{ Adjusted R Square } & 0.89 & & & & & \\
\hline \multicolumn{2}{|l|}{ Standard Error } & 7.62 & & & & & \\
\hline \multicolumn{2}{|l|}{ Observations } & 4 & & & & & \\
\hline & Coefficients & & $P$-value & $\begin{array}{l}\text { Lower } \\
95 \%\end{array}$ & Upper $95 \%$ & $\begin{array}{l}\text { Lower } \\
95.0 \%\end{array}$ & Upper $95.0 \%$ \\
\hline Intercept & 105.352236 & & 0.07 & -21.47 & 232.18 & -21.47 & 232.18 \\
\hline X Variable 1 & 957.9282817 & & 0.04 & 122.18 & 1793.68 & 122.18 & 1793.68 \\
\hline
\end{tabular}

Table 4.2. Regression Test

Further, the percentages of the average relationship between the variables were 92 percent. Therefore, the test further reveals that there are high possibility for calculating the doubling time of the research publications.

\subsection{Doubling Time of Research Publications}

\begin{tabular}{|c|c|c|c|c|c|c|c|c|c|c|}
\hline \multirow{2}{*}{ Year } & \multirow{2}{*}{$\begin{array}{l}\text { No. of } \\
\text { Records }\end{array}$} & \multirow{2}{*}{$\begin{array}{l}\text { Cumulative } \\
\text { Records }\end{array}$} & \multirow{2}{*}{ W1 } & \multirow{2}{*}{ W2 } & \multirow{2}{*}{$\mathbf{R}(\mathbf{P})$} & \multirow{2}{*}{ 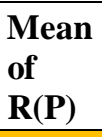 } & \multirow{2}{*}{$\begin{array}{l}\text { DT }= \\
0.693 / R P\end{array}$} & \multirow{2}{*}{$\begin{array}{l}\text { Average } \\
\text { Doubling } \\
\text { Time }\end{array}$} & \multicolumn{2}{|c|}{ Doubling Time } \\
\hline & & & & & & & & & Days & Months \\
\hline 2011 & 227 & 227 & 5.42 & 5.42 & 0.00 & \multirow{4}{*}{0.75} & & \multirow{4}{*}{0.75} & \multirow{4}{*}{$\begin{array}{l}270 \\
\text { Days }\end{array}$} & \multirow{4}{*}{9 months } \\
\hline 2012 & 234 & 461 & 5.46 & 6.13 & 0.68 & & 1.02 & & & \\
\hline 2013 & 263 & 724 & 5.57 & 6.58 & 1.01 & & 0.68 & & & \\
\hline 2014 & 274 & 998 & 5.61 & 6.91 & 1.29 & & 0.54 & & & \\
\hline 2015 & 316 & 1314 & 5.76 & 7.18 & 1.43 & \multirow{4}{*}{1.59} & 0.49 & \multirow{4}{*}{0.44} & \multirow{4}{*}{$\begin{array}{l}158 \\
\text { Days }\end{array}$} & \multirow{4}{*}{$\begin{array}{l}5 \text { Months } \\
\text { and } 8 \\
\text { Days }\end{array}$} \\
\hline 2016 & 353 & 1667 & 5.87 & 7.42 & 1.55 & & 0.45 & & & \\
\hline 2017 & 391 & 2058 & 5.97 & 7.63 & 1.66 & & 0.42 & & & \\
\hline 2018 & 449 & 2507 & 6.11 & 7.83 & 1.72 & & 0.40 & & & \\
\hline
\end{tabular}

Table 4.3. Doubling Time of Research Publications

The eight years research publications from 2011 to 2018 have been segregated into two block years (i.e., from 2011 to 2014 and from 2015 to 2018) to assess the doubling time of the research productivity. On the basis of the number of research productivity from 2011 to 2014, the doubling time of records is assessed as 270 days or 9 months. On the basis of the number of research productivity from 2015 to 2018, the doubling time of records is assessed as 158 days or 5 months and 8 days. 
4.4Type of Research Publications on Water Conservation

\begin{tabular}{|c|c|c|c|c|c|c|c|c|c|}
\hline & & & & & & & & & \\
\hline & & & & Local Cita & ion Sco & & & & \\
\hline S. No. & $\begin{array}{l}\text { Document } \\
\text { Type }\end{array}$ & $\begin{array}{l}\text { Research } \\
\text { Publications }\end{array}$ & $\begin{array}{l}\% \\
\text { Analysis }\end{array}$ & $\begin{array}{l}\text { Including } \\
\text { Self } \\
\text { Citation } \\
\end{array}$ & $\begin{array}{l}\text { h } \\
\text { Index }\end{array}$ & $\begin{array}{l}\text { Excluding } \\
\text { Self } \\
\text { Citation }\end{array}$ & $\begin{array}{l}\text { h } \\
\text { Index }\end{array}$ & $\begin{array}{l}\text { Citation } \\
\text { Score }\end{array}$ & $\begin{array}{l}\text { h } \\
\text { Index }\end{array}$ \\
\hline 1 & Article & 2307 & $92.02 \%$ & 1957 & 14 & 1365 & 12 & 25580 & 58 \\
\hline 2 & Review & 126 & $5.03 \%$ & 105 & 5 & 75 & 4 & 2531 & 29 \\
\hline 3 & $\begin{array}{l}\text { Article; } \\
\text { Proceedings } \\
\text { Paper }\end{array}$ & 34 & $1.36 \%$ & 14 & 2 & 7 & 2 & 145 & 6 \\
\hline 4 & $\begin{array}{l}\text { Editorial } \\
\text { Material }\end{array}$ & 18 & $0.72 \%$ & 4 & 2 & 2 & 1 & 43 & 3 \\
\hline 5 & News Item & 6 & $0.24 \%$ & 0 & 0 & 0 & 0 & 1 & 1 \\
\hline 6 & $\begin{array}{l}\text { Review; } \\
\text { Book } \\
\text { Chapter }\end{array}$ & 5 & $0.20 \%$ & 25 & 2 & 22 & 1 & 131 & 4 \\
\hline 7 & $\begin{array}{l}\text { Meeting } \\
\text { Abstract }\end{array}$ & 4 & $0.16 \%$ & 0 & 0 & 0 & 0 & 1 & 1 \\
\hline 8 & $\begin{array}{l}\text { Article; Book } \\
\text { Chapter }\end{array}$ & 2 & $0.08 \%$ & 1 & 1 & 0 & 0 & 54 & 2 \\
\hline 9 & $\begin{array}{l}\text { Article; } \\
\text { Retracted } \\
\text { Publication }\end{array}$ & 2 & $0.08 \%$ & 2 & 1 & 2 & 1 & 20 & 2 \\
\hline 10 & Correction & 2 & $0.08 \%$ & 0 & 0 & 0 & 0 & 0 & 0 \\
\hline 11 & $\begin{array}{l}\text { Biographical- } \\
\text { Item }\end{array}$ & 1 & $0.04 \%$ & 0 & 0 & 0 & 0 & 0 & 0 \\
\hline Total & & 2507 & $100.00 \%$ & 2108 & 27 & 1473 & 21 & 28506 & 106 \\
\hline
\end{tabular}

Table No.4.4 Type of Research Publications on Water Conservation

The table number 4.4. is crystal clear that 11 type of publications are involved in publishing research literatures on "Water Conservation". The type of document "Article" played vital role in publishing 2307(92.02\%) publications and played dominant role. "Articles" received a local citation score of 1957, which includes the self-citation and gained an h-Index of 14. "Articles" received the local citation score of 1365, which excludes the selfcitationand gained an h-Index of 12. "Articles" received 25580 global citation score and gained an h-Index of 58. "Reviews" placed second top in the table number 4.4. with $126(5.03 \%)$ research reviews. Papers published in conference proceedings placed in the third place with a publication count of 34(1.36\%) followed by Editorial material 18(0.72\%); News items 6(0.24\%); Review of the Book Chapters 5(0.20\%); Meeting abstracts 4(0.16\%); Book chapters and retracted publications with 2(0.08\%); Correction 2(0.08\%) and Bibliographical item with only $1(0.04 \%)$ publication.

\subsection{Language wise Research Publications on Water Conservation}


The table number 4.5 shows that nine languages are involved towards publishing 2507 research publications on "Water Conservation". The language "English" played majority role with a maximum publication count of 2467(98.40\%) publications. English language publications of 2467 received a local citation score of 2103, which is including self citation and the same gained an h-Index of 15 . The local citation score of 1471, which is excluding self-citation for the "English" language gained an h-Index of 12. "English" language publications received a global citation score of 28407 and gained an h-Index of 61 . "Portuguese" language placed in the second place with a publication count of 20nos. $(0.80 \%)$. The language "Spanish" placed in the third place with a publication count of 7 nos. $(0.28 \%)$ followed by French 5nos.(0.20\%); German 3nos. (0.12\%); Turkish 2(0.08\%); Chinese, Duthch and Polish with $1(0.04 \%)$ publication.

\begin{tabular}{|c|c|c|c|c|c|c|c|c|c|}
\hline \multirow[b]{2}{*}{$\begin{array}{l}\text { S. } \\
\text { No. }\end{array}$} & \multirow{2}{*}{$\begin{array}{l}\text { Language } \\
\text { wise } \\
\text { Publicatio } \\
\text { ns }\end{array}$} & \multirow{2}{*}{$\begin{array}{l}\text { No. of } \\
\text { Research } \\
\text { Publicatio } \\
\text { ns }\end{array}$} & \multirow[b]{2}{*}{$\begin{array}{l}\% \\
\text { Analysi } \\
\text { s }\end{array}$} & \multicolumn{4}{|c|}{ Local Citation Score } & \multirow{2}{*}{$\begin{array}{l}\text { Global } \\
\text { Citatio } \\
\text { n } \\
\text { Score } \\
\end{array}$} & \multirow[b]{2}{*}{$\begin{array}{l}\text { h } \\
\text { Inde } \\
x\end{array}$} \\
\hline & & & & $\begin{array}{l}\text { Includin } \\
\text { g Self } \\
\text { Citation } \\
\end{array}$ & $\begin{array}{l}\mathbf{h} \\
\text { Inde } \\
\mathbf{x} \\
\end{array}$ & $\begin{array}{l}\text { Excludin } \\
\text { g Self } \\
\text { Citation } \\
\end{array}$ & $\begin{array}{l}\mathbf{h} \\
\text { Inde } \\
x \\
\end{array}$ & & \\
\hline 1 & English & 2467 & $98.40 \%$ & 2103 & 15 & 1471 & 12 & 28407 & 61 \\
\hline 2 & Portuguese & 20 & $0.80 \%$ & 4 & 1 & 2 & 1 & 68 & 6 \\
\hline 3 & Spanish & 7 & $0.28 \%$ & 0 & 0 & 0 & 0 & 9 & 2 \\
\hline 4 & French & 5 & $0.20 \%$ & 1 & 1 & 0 & 0 & 12 & 3 \\
\hline 5 & German & 3 & $0.12 \%$ & 0 & 0 & 0 & 0 & 0 & 0 \\
\hline 6 & Turkish & 2 & $0.08 \%$ & 0 & 0 & 0 & 0 & 1 & 1 \\
\hline 7 & Chinese & 1 & $0.04 \%$ & 0 & 0 & 0 & 0 & 5 & 1 \\
\hline 8 & Dutch & 1 & $0.04 \%$ & 0 & 0 & 0 & 0 & 0 & 0 \\
\hline 9 & Polish & 1 & $0.04 \%$ & 0 & 0 & 0 & 0 & 4 & 1 \\
\hline \multicolumn{2}{|c|}{ Total } & 2507 & $100 \%$ & 2108 & 17 & 1473 & 13 & 28506 & 75 \\
\hline
\end{tabular}

Table 4.5. Language wise Research Publications on Water Conservation

\subsection{Application and Testing of Lotka's Law}

Alfred Lotka's author productivity theory has been applied for the research publications on"Water Conservation" and tested with Kolmogorov Smirnov Test. The meaning of the theory of Alfred Lotka's law is the entire number of productivity of publications are based on the inverse square of the total number of publications published by single author. Therefore, appropriate hypothesis has been framed and tested with KS test. The hypothesis is as follows:

H0: There is no significant relationship between the actual author productivity and the prediction of Alfred Lotka's author productivity theory.

The observed frequency has been found out. Lotka's Power Law has been applied to find out the expected frequency. The d-max (i.e., maximum deviation) between the observed frequency and the expected frequency is 0.63925 . The Threshold Value is 0.03255 . Since the d-max value of 0.63925 is greater than the Threshold Value of 0.03255 , the null hypothesis is 
accepted. Therefore, the Kolmogorov Smirnov Test proves that the Lotka's Law does not fit for the author productivity of the research publications published on "Water Conservation".

\begin{tabular}{|c|c|c|c|c|c|c|c|c|c|c|c|c|}
\hline $\mathbf{x}$ & $\mathbf{y}$ & $\begin{array}{l}X \\
(\log x)\end{array}$ & $\begin{array}{l}Y \\
(\operatorname{logy})\end{array}$ & $\mathbf{X Y}$ & $\mathbf{X X}$ & "D" & $\begin{array}{l}\text { cum=" } \\
\text { O" }^{\prime \prime}\end{array}$ & $\begin{array}{l}\text { cum. } \\
\text { "y" }\end{array}$ & $1 / x n$ & fe & $\begin{array}{l}\text { cum } \\
\text { fe }\end{array}$ & Dif \\
\hline 1 & 160 & 0.00 & 2.20 & 0.00 & 0.00 & 0.0638 & 0.0638 & 160 & 1 & 0.7031 & 0.7031 & 0.63925 \\
\hline 2 & 395 & 0.30 & 2.60 & 0.78 & 0.09 & 0.1576 & 0.2214 & 555 & 0.20448 & 0.1438 & 0.8468 & 0.62545 \\
\hline 3 & 535 & 0.48 & 2.73 & 1.30 & 0.23 & 0.2134 & 0.4348 & 1090 & 0.08080 & 0.0568 & 0.9036 & 0.46885 \\
\hline 4 & 477 & 0.60 & 2.68 & 1.61 & 0.36 & 0.1903 & 0.6250 & 1567 & 0.04181 & 0.0294 & 0.9330 & 0.30798 \\
\hline 5 & 360 & 0.70 & 2.56 & 1.79 & 0.49 & 0.1436 & 0.7686 & 1927 & 0.02508 & 0.0176 & 0.9507 & 0.18202 \\
\hline 6 & 239 & 0.78 & 2.38 & 1.85 & 0.61 & 0.0953 & 0.8640 & 2166 & 0.01652 & 0.0116 & 0.9623 & 0.09830 \\
\hline 7 & 133 & 0.85 & 2.12 & 1.79 & 0.71 & 0.0531 & 0.9170 & 2299 & 0.01161 & 0.0082 & 0.9704 & 0.05341 \\
\hline 8 & 80 & 0.90 & 1.90 & 1.72 & 0.82 & 0.0319 & 0.9489 & 2379 & 0.00855 & 0.0060 & 0.9765 & 0.02751 \\
\hline 9 & 45 & 0.95 & 1.65 & 1.58 & 0.91 & 0.0179 & 0.9669 & 2424 & 0.00653 & 0.0046 & 0.9810 & 0.01415 \\
\hline 10 & 34 & 1.00 & 1.53 & 1.53 & 1.00 & 0.0136 & 0.9805 & 2458 & 0.00513 & 0.0036 & 0.9846 & 0.00419 \\
\hline 11 & 17 & 1.04 & 1.23 & 1.28 & 1.08 & 0.0068 & 0.9872 & 2475 & 0.00412 & 0.0029 & 0.9875 & 0.00031 \\
\hline 12 & 9 & 1.08 & 0.95 & 1.03 & 1.16 & 0.0036 & 0.9908 & 2484 & 0.00338 & 0.0024 & 0.9899 & 0.00091 \\
\hline 13 & 1 & 1.11 & 0.00 & 0.00 & 1.24 & 0.0004 & 0.9912 & 2485 & 0.00281 & 0.0020 & 0.9919 & 0.00067 \\
\hline 14 & 6 & 1.15 & 0.78 & 0.89 & 1.31 & 0.0024 & 0.9936 & 2491 & 0.00237 & 0.0017 & 0.9936 & 0.00005 \\
\hline 15 & 5 & 1.18 & 0.70 & 0.82 & 1.38 & 0.0020 & 0.9956 & 2496 & 0.00203 & 0.0014 & 0.9950 & 0.00062 \\
\hline 16 & 2 & 1.20 & 0.30 & 0.36 & 1.45 & 0.0008 & 0.9964 & 2498 & 0.00175 & 0.0012 & 0.9962 & 0.00019 \\
\hline 17 & 2 & 1.23 & 0.30 & 0.37 & 1.51 & 0.0008 & 0.9972 & 2500 & 0.00152 & 0.0011 & 0.9973 & 0.00008 \\
\hline 20 & 1 & 1.30 & 0.00 & 0.00 & 1.69 & 0.0004 & 0.9976 & 2501 & 0.00105 & 0.0007 & 0.9980 & 0.00042 \\
\hline 21 & 1 & 1.32 & 0.00 & 0.00 & 1.75 & 0.0004 & 0.9980 & 2502 & 0.00094 & 0.0007 & 0.9987 & 0.00068 \\
\hline 24 & 1 & 1.38 & 0.00 & 0.00 & 1.90 & 0.0004 & 0.9984 & 2503 & 0.00069 & 0.0005 & 0.9992 & 0.00077 \\
\hline 26 & 2 & 1.41 & 0.30 & 0.43 & 2.00 & 0.0008 & 0.9992 & 2505 & 0.00058 & 0.0004 & 0.9996 & 0.00037 \\
\hline 29 & 1 & 1.46 & 0.00 & 0.00 & 2.14 & 0.0004 & 0.9996 & 2506 & 0.00045 & 0.0003 & 0.9999 & 0.00029 \\
\hline 46 & 1 & 1.66 & 0.00 & 0.00 & 2.76 & 0.0004 & 1.0000 & 2507 & 0.00016 & 0.0001 & 1.0000 & 0.00000 \\
\hline Total & 2507 & 23.09 & 26.92 & 19.14 & 26.62 & 1.00 & & & 1.4223 & 1 & & \\
\hline
\end{tabular}

Table 4.6. Application and Testing of Lotka's Law

\begin{tabular}{|l|l|}
\hline n value & 2.29 \\
\hline c value & 1.4223 \\
\hline d MAX & 0.63925 \\
\hline Threshold Value & 0.03255 \\
\hline
\end{tabular}


Table 4.6.1. Results of Kolmogorov Smirnov Test to assess the fitness of Lotka's Law

\subsection{Application of Bradford's Law}

The table number 4.7.1 shows the details of the number of journals categorized into three zones through the application of Bradford's Law. The first zone consists of 25 journals, which are in-charge of the publications of 773 journal articles. The second zone consists of 109 journals, which are responsible for the publication of 769 journal articles. The third zone consists of 539 journals, which are responsible for the publication of 765 journal articles. According to Bradford's Law, the first zone, which consists of 25 journals and 773 articles are most prolific. The prolific concept of this lawreveals that the library can be benefitted by procuring 25 journals and enjoy the privilege of accessing 773 journal articles.

\begin{tabular}{|l|l|l|}
\hline Zone & No. Of Journals & No. Of Journal Articles \\
\hline 1 & 25 & 773 \\
\hline 2 & 109 & 769 \\
\hline 3 & 539 & 765 \\
\hline
\end{tabular}

Table 4.7.1 Zone segregated through the application of Bradford's Law

\begin{tabular}{|c|c|c|c|c|c|c|c|c|}
\hline \multirow[b]{2}{*}{$\begin{array}{l}\text { S. } \\
\text { No. }\end{array}$} & \multirow[b]{2}{*}{ Name of the Journal } & \multirow[b]{2}{*}{$\begin{array}{l}\text { No. of } \\
\text { Articles }\end{array}$} & \multicolumn{4}{|c|}{ Local Citation Score } & \multirow[b]{2}{*}{$\begin{array}{l}\text { Global } \\
\text { Citation } \\
\text { Score }\end{array}$} & \multirow[b]{2}{*}{$\begin{array}{l}\mathrm{h} \\
\text { Index }\end{array}$} \\
\hline & & & $\begin{array}{l}\text { Including } \\
\text { Self } \\
\text { Citation } \\
\end{array}$ & $\begin{array}{l}\text { h } \\
\text { Index }\end{array}$ & $\begin{array}{l}\text { Excluding } \\
\text { Self } \\
\text { Citation }\end{array}$ & $\begin{array}{l}\text { h } \\
\text { Index }\end{array}$ & & \\
\hline 1 & Water & 61 & 9 & 2 & 6 & 1 & 275 & 9 \\
\hline 2 & $\begin{array}{ll}\text { Land Degradation } & \& \\
\text { Development } & \\
\end{array}$ & 48 & 124 & 6 & 96 & 5 & 1086 & 17 \\
\hline 3 & $\begin{array}{lll}\begin{array}{l}\text { Journal } \\
\text { Production }\end{array} & \text { Cleaner } \\
\end{array}$ & 47 & 62 & 3 & 51 & 3 & 664 & 14 \\
\hline 4 & $\begin{array}{ll}\text { Agricultural } & \text { Water } \\
\text { Management } & \end{array}$ & 43 & 35 & 3 & 29 & 3 & 815 & 17 \\
\hline 5 & Catena & 42 & 58 & 4 & 40 & 3 & 666 & 14 \\
\hline 6 & Journal of Hydrology & 42 & 56 & 4 & 30 & 3 & 895 & 17 \\
\hline 7 & Sustainability & 39 & 0 & 0 & 0 & 0 & 83 & 6 \\
\hline 8 & $\begin{array}{ll}\text { Environmental } & \text { Earth } \\
\text { Sciences } & \end{array}$ & 37 & 22 & 3 & 16 & 2 & 323 & 11 \\
\hline 9 & $\begin{array}{l}\text { Journal of Environmental } \\
\text { Management }\end{array}$ & 34 & 144 & 6 & 125 & 5 & 773 & 14 \\
\hline 10 & $\begin{array}{ll}\text { Water } & \text { Resources } \\
\text { Management } & \\
\end{array}$ & 34 & 44 & 3 & 36 & 3 & 433 & 14 \\
\hline 11 & $\begin{array}{l}\text { Science of the Total } \\
\text { Environment }\end{array}$ & 32 & 56 & 5 & 38 & 3 & 719 & 16 \\
\hline
\end{tabular}




\begin{tabular}{|l|l|l|l|l|l|l|l|l|}
12 & $\begin{array}{l}\text { Journal of Soil and Water } \\
\text { Conservation }\end{array}$ & 31 & 16 & 2 & 9 & 2 & 397 & 10 \\
\hline 13 & PLOS ONE & 29 & 0 & 0 & 0 & 0 & 323 & 11 \\
\hline 14 & $\begin{array}{l}\text { Journal of American Water } \\
\text { Works Association }\end{array}$ & 27 & 16 & 2 & 16 & 2 & 70 & 5 \\
\hline 15 & Soil \& Tillage Research & 26 & 19 & 2 & 12 & 2 & 368 & 11 \\
\hline 16 & Water Resources Research & 25 & 17 & 3 & 13 & 2 & 333 & 12 \\
\hline 17 & $\begin{array}{l}\text { Land Use Policy } \\
\text { Journal of the American } \\
\text { Water Resources } \\
\text { Association }\end{array}$ & 22 & 22 & 3 & 14 & 2 & 171 & 8 \\
\hline 19 & Environmental Management & 21 & 17 & 3 & 9 & 2 & 230 & 9 \\
\hline 20 & $\begin{array}{l}\text { Environmental Monitoring } \\
\text { and Assessment }\end{array}$ & 21 & 14 & 3 & 14 & 1 & 196 & 8 \\
\hline 21 & $\begin{array}{l}\text { Resources Conservation and } \\
\text { Recycling }\end{array}$ & 20 & 48 & 4 & 36 & 3 & 453 & 13 \\
\hline 22 & $\begin{array}{l}\text { Journal of Irrigation and } \\
\text { Drainage Engineering }\end{array}$ & 18 & 13 & 1 & 3 & 1 & 77 & 3 \\
\hline 23 & Water Policy & 17 & 9 & 2 & 6 & 1 & 100 & 5 \\
\hline 24 & $\begin{array}{l}\text { Water Science and } \\
\text { Technology-Water Supply }\end{array}$ & 17 & 1 & 1 & 1 & 1 & 28 & 3 \\
\hline 25 & HORTSCIENCE & 16 & 8 & 2 & 5 & 1 & 83 & 5 \\
\hline Total & $\mathbf{7 7 3}$ & $\mathbf{8 2 7}$ & $\mathbf{6 9}$ & $\mathbf{6 1 8}$ & $\mathbf{5 3}$ & $\mathbf{9 8 9 3}$ & $\mathbf{2 6 2}$ \\
\hline
\end{tabular}

Table 4.7.2. Zone 1: Core Journals According to Bradford's Law

The Bradford's Law has been applied to find out the most productive journals responsible for the publication of the majority of articles on "Water Conservation". The table number 4.7.2 reveals the zone 1, which consists of 25 titles of journals in-charge of publishing 773 journal articles. The journal entitled "Water" placed first in the table with a maximum article count of 61 numbers, for which the journal received a local citation score (including self-citation) of 9nos. and gained 2 as h-Index. The journal also received a local citation score of 6nos. which excludes the self-citation score and gained one as h-Index .The journal entitled "Water" received a global citation score of 275 and 9 as h-Index.

\section{Conclusion}

"Water" is a God given natural resource, which is very much essential to safeguard the life of each and every living being of this world. The conservation of water should be 
embedded in the sense of each and every human being to protect the contemporary generation and as well as the future generation. "Water" has to be conserved properly because "excess of water" or "lacuna of water" will leads to disaster. In an intention to bring out the current status of the research output on "Water Conservation", this scientometric study has been articulated. The year wise efforts of the global scientists towards publishing research publications on "Water Conservation" are in increasing trend, which is appreciable as the act reveals about the care taking responsibility of the contributors. The doubling time proves that the publications are in increasing trend. English language played vital role, which further proves that propagation about the importance of "Water Conservation" has already been communicated to the majority of the countries in the world. Journal articles played dominant role among the other type of publications, which shows very clearly about the quality of the research. Further, the findings through the scientometric research proved that Alfred Lotka's Law does not fit to the author productivity of the publications on "Water Conservation". Through the Bradford's Law the core journals are identified. Through this research work, it is suggested that each and every ministry of global countries leading the role of protecting the natural resources and the sponsoring bodies towards the same should encourage their respective scientists to contribute more towards the enhancement of the "Water Conservation" in an intention to take absolute care of the society and to make the living beings of the society to live and lead a happy long life.

\section{References}

[1] Liu, Z., Lu, Y., \&Peh, L. C. (2019). A Review and Scientometric Analysis of Global Building Information Modelling (BIM) Research in the Architecture, Engineering and Construction (AEC) Industry Buildings 9.10 (2019): 210

[2] Sivasamy, K., \&Vivekanandhan, S. (2015). Environmental education research literature output in SCOPUS database (2009-2013): A bibliometric study. International Journal of Information Sources and Services, 2(2), 84-93.

[3] Morooka, K., Ramos, M. M., \& Nathaniel, F. N. (2014). A bibliometric approach to interdisciplinarity in Japanese rice research and technology development. Scientometrics, 98(1), 73-98.

[4] Ren, J. L., Lyu, P. H., Wu, X. M., Ma, F. C., Wang, Z. Z., \& Yang, G. (2013). An informetric profile of water resources management literatures. Water resources management, 27(13), 46794696.

[5] Biglu, M. H., Eskandari, F., \&Asgharzadeh, A. (2011).Scientometric analysis of nanotechnology in MEDLINE. BioImpacts: BI, 1(3), 193.

[6] Muthuraj, Surulinathi; Balasubramani, R.; and N, AMSAVENI, "COVID-19 research output in 2020: The Global Perspective using Scientometric Study" (2020).Library Philosophy and Practice, 4196. https://digitalcommons.unl.edu/libphilprac/4196

[7] Gunasekera, Chamani and Balasubramani, R., "Information Seeking Pattern of School Teachers in Sri Lanka: Discovering the Associate Factors" (2020). Library Philosophy and Practice (e-journal). 3699. https://digitalcommons.unl.edu/libphilprac/3699

[8] J, Arumugam and R, Balasubramani, "Scholarly Research Output of Kumaraguru College of Technology, Coimbatore: Scientometric Analysis" (2020). Library Philosophy and Practice, 4158. https://digitalcommons.unl.edu/libphilprac/4158

[9] Surulinathi, M., Balasubramani, R., \&Kalisdha, A. (2013). Continent wise Analysis of Green Computing Research: a scientometric study. Journal of Advances in Library and Information Science, 2(1), 39-44.

[10] Balasubramani, R., \&Parameswaran, R. (2014). Mapping the research productivity of Banaras Hindu University: A scientometric study. Journal of Theoretical and Applied Information Technology, 59(2), 367-371. 
[11] Sivasekaran, K., \&Srinivasaragavan, S. S. (2013). Mapping of research publications on Himalayas: A scientometrics exploration. International Journal of Scientific Research, 2(3), 58-60.

[12] Sivasekaran, K. (2015). India's Contribution on Renewable Energy Research Output: A Scientometric Study. Journal of Advances in Library and Information Science, 4(4), 311-316.

[13] pichai, janarthanan; Stanleay, . PrabakarDr.; and Kannan, .NithyanandamDr., "Dengue Hemorrhagic Fever: A Scientometric Study" (2019). Library Philosophy and Practice (ejournal). 3694. https://digitalcommons.unl.edu/libphilprac/3694

[14] Janaarthanan, Pichai Mr; Prabhakar, Stanleay Dr; and Nithayanandham, Kannan Dr, "Research Impact on Drone by means of Scientometric Analysis" (2019). Library Philosophy and Practice,2897.https://digitalcommons.unl.edu/libphilprac/2897

[15] Ramasamy, R. U., Sivasekaran, K., \&Navasakathi, C. (2013). Scientometric Analysis of Thorium Research in India: A Case study. Global Research Analysis, 4, 80-82.

[16] Ashok Kumar, P., Navalur, S. A., \&Sivasekaran, K. (2013). A Scientometric Study of Biodiversity Research in India: A special r. International Journal of Scientific Research.

[17] Gupta, B. M., Dhawan, S. M., Kumar, A., \&Visakhi, P. (2018). E-Waste Research: A Scientometric Assessment of Global Publications Output during 2007-16. International Journal of Information Dissemination and Technology, 8(1), 31-36.

[18] Sivasekaran, K Dr.; Stanleay, Prabakar Dr.; and Ashok Kumar, P Dr., "Mapping the Study and Awareness on Early Death Research: A scientometric Analysis" (2020). Library Philosophy and Practice, 4368. https://digitalcommons.unl.edu/libphilprac/4368

[19] Kamatchi, SivasekaranDr.;Stanleay, PrabakarDr.; Subramanian, ChithiraivelDr.; P, Ashok Kumar Dr.; and Arumugam, ThirumagalDr., "Electric Car: A Research Impact BY Means OF Scientometric Analysis" (2019). Library Philosophy and Practice, 3660. https://digitalcommons.unl.edu/libphilprac/3660.

[20] Vivekanandhan, S., Sivasamy, K., \&Prabhakar, S. (2016). Publications and Citations Analysis of Pollution Control Research Output from SCOPUS Database: A Scientometrics Analysis. International Journal of Next Generation Library and Technologies, 2(3), 1-13.

[21] Sivankalai, S., \&Badhusha, K. N. (2020). Bibliometric study on COVID 19 Outbreak. International Journal of Library and Information Studies, 10(2), 1-19.

[22] Kademani, B. S., Vijai, K., Anil, S., Anil, K., Lalit, M., \&Surwase, G. (2006). Scientometric dimensions of thorium research in India. DESIDOC Bulletin of Information Technology, 26(3), 9-25.

[23] Bala, A., \& Gupta, B. M. (2010). Mapping of Indian neuroscience research: A scientometric analysis of research output during 1999-2008. Neurology India, 58(1), 35.

[24] Trivedi, Guptnath, "Scholarly Communication in International Journal of Digital Curation from 2006-2017: a DOAJ based study" (2019). Library Philosophy and Practice (e-journal). 2866. https://digitalcommons.unl.edu/libphilprac/2866

[25] Gupta, Brij Mohan Dr and Gupta, Ritu, "A Scientometric Assessment of Indian Himalayan R\&D Publications during 2004-13" (2014). Library Philosophy and Practice (e-journal). 1203. http://digitalcommons.unl.edu/libphilprac/1203

[26] https://www.toppr.com/guides/geography/water-resources/an-introduction-to-water-resources/. 